miles of existing sewers located. Over the greater part of the district the clay is overlaid with about twenty feet of water-bearing ballast and, to avoid trouble, the sewers were located in the clay, in which tunnelling is comparatively easy. In this connexion, the author notes that the contractors showed a growing preference for tunnelling, as it eliminated the heavy road charges and the costs and delays of diverting gas, water and other mains which open trench work involves.

A circular section was adopted for all sizes of sewers, as the higher velocity at low flows which might be expected from the egg-shaped section was deemed to be outweighed by the advantages of lower cost, increased resistance to external pressure and less loss of head. The lining of the larger sewers was best engineering brickwork, while pipes of aluminous cement were principally used in those less than $4 \mathrm{ft}$. in diameter. Although these tubes have a smoother surface initially, it was held that, over a long period, the average surface of brickwork is better; the roughness coefficients used in the Flynn-Kutter formula were 0.013 for brick, cast-iron and glazed stoneware, and 0.015 for cement pipes. The paper gives many valuable notes on the design of sewers, and describes the methods of effecting the junction of the local sewerage systems with the main trunk sewers. As the latter are at many points at a depth of 60 feet below ground, the design of backdrops and cascades forms an important feature, and several of these and the methods of effecting flood relief of the rivers are illustrated.

For the purpose of ensuring that each district gets its fair share of the use of the sewers and of providing as much research information as possible of local storms and flows, a complete system of gauging has been installed. For various reasons, standing wave flumes were considered most suitable, and from tests made it is anticipated that a degree of accuracy of two per cent at full flow to six per cent at one thirtieth flow can be obtained.

At the Mogden works the purification of the liquid sewage is effected by the sludge activation process, and to ensure freedom from smell and also to utilize the available gas for power and heat, the sludge is subjected to complete anærobic digestion. Large storm-water tanks have been constructed and these are in continuous use for partial treatment. In a partially digested state, the sludge is pumped seven miles to Perry Oaks, where the secondary digestion, drying and final disposal by tipping are carried out. The complete isolation of the drying beds from adjacent lands has been ensured by sinking a puddle wall through pervious clay and keying it into the London Clay. This method is regarded as unique, and was a necessary and wise precaution to prevent soakage finding its way into potable water. By means of this scheme, which was completed in May 1936, twenty-seven small sewerage works have been replaced by one large system.

\title{
Museums and the People
}

A

$T$ the present time museums, taking them all in all, are undergoing an interesting and critical stage of development. Some began and remain as collections of curios and some have degenerated to that condition, but the majority are striving in one way or another to test the reactions of the community, in efforts to discover the lines which hold out most hope of stimulating interest. The success or failure of these efforts is a matter of moment to the people as well as to the museums themselves, for upon it depends the place which museums are to take in the life of the community as centres of education and of intellectual and æsthetic pleasure. For many of our local museums, perhaps for most, this place is still undecided, and accordingly advice upon the most promising lines of progress by a museum official of experience and standing ought to fall upon open ears.

At the Newcastle conference of the Museums Association held in July, Dr. W. E. Swinton of the British Museum (Natural History), in a paper which has appeared in the Museums Journal (September), gave sound advice upon the improvement of collections. He justly pointed to the hesitancy of many municipalities to give proper financial backing to the museums under their care, a hesitancy to be observed particularly in the appointment of suitably paid curators with knowledge and training for posts which have their own peculiar difficulties and make their own special demands. Thanks to an awakening conscience and to the efforts of the Carnegie United Kingdom Trust, that position is improving, and "many municipal authorities to-day feel, though vaguely it may be, that a natural history museum is somehow an asset to the community".

Granted a suitable curator, what of the collections themselves? In the first place the local natural history museum should concern itself with the objects of its own neighbourhood, and secondly, it should present these in such a way that the visitor should be induced to take a fresh or increased interest in the local fauna, flora and geology. That implies ruthless elimination of surplus specimens, so that room may be gained for a few well-selected groups in natural habitats, well lit and clearly, instructively and yet simply labelled.

Dr. Swinton properly suggests that no zoological series is complete without the inclusion of fossil forms in their systematic position, presumably to illustrate the course of evolution. But why not take the bull by the horms and arrange selected series specially to illustrate evolution and other general truths, for that would be education at its best; and the ordinary visitor who could visualize evolution from the systematic exhibits of most museums would be a miracle himself. The time will come when systematic collections, except for the merest skeleton of classification and other defined purposes, will be relegated to cabinets where identifications and detailed comparisons can best be made, and galleries will largely be given over to exhibits which stimulate observation of the habits and adaptations of living things, and which lead visitors gently to appreciation of the great truths which lie behind structure and development and evolutionary progress. J. R. 